\title{
IDENTIFIKASI PANGAN TRADISIONAL DI KABUPATEN KEPAHIANG PROVINSI BENGKULU
}

\section{IDENTIFICATION OF TRADITIONAL FOOD IN KEPAHIANG DISTRICK BENGKULU PROVINCE}

\author{
Reni Yunita, Hesti Nur'aini \\ Program Studi Teknologi Pertanian Fakultas Pertanian, Universitas Dehasen Bengkulu \\ Email : hestinuraini1996@mail.com
}

\begin{abstract}
ABSTRAK
Pangan lokal adalah pangan tradisional yang dihasilkan dari suatu daerah di Indonesia yang terdiri dari berbagai macam makanan pokok, maupun makanan ringan. Pangan tradisional adalah pangan yang sudah turun temurun dihasilkan atau dikonsumsi, menggunakan bahan lokal dan diolah secara khas di suatu daerah. Penelitian ini bertujuan untuk mengidentifikasi jenis produk pangan lokal dan menganalisis sifat makronutrien yang terdapat dalam makanan tradisional di Kabupaten Kepahiang, Analisis penelitian ini menggunakan analisis deskriptif.

Hasil analisis menunjukkan bahwa pangan tradisional di Kabupaten Kepahiang terdiri dari 18 jenis makanan yaitu 8 jenis jajanan, 4 jenis lauk pauk dan 6 jenis minuman. Analisis makronutrien pada lemang mengandung 3,98 \% protein, 4,93\% lemak dan 23,45 $\%$ karbohidrat. Serawo mengandung 3,87\% protein, 5,12\% lemak dan $22,89 \%$ karbohidrat, sedangkan bajik mengandung 3,67 \% protein, 5,45\% lemak dan 22,54\% karbohidrat.
\end{abstract}

Kata kunci: pangan tradisional, Kabupaten Kepahiang, makronutrien

\section{ABSTRACT}

Local food is a traditional food that is produced from an area in Indonesia that consists of a wide variety of staple foods, and snacks. Traditional food is food that has been handed down generated or consumed, using local materials and processed typically in an area. This study aims to identify the types of local food products and analyze the nature of macronutrients contained in traditional foods in Kepahiang District, this study analysis using descriptive analysis.

The analysis showed that the traditional food in Kepahiang District consists of 18 types of foods are 8 types of snacks, 4 kinds of side dishes and 6 different types of drinks. Analysis macronutrient in lemang containing $3.98 \%$ protein, $4.93 \%$ fat and $23.45 \%$ carbohydrates. Serawo containing $3.87 \%$ protein, $5.12 \%$ fat and carbohydrates $22.89 \%$, while the virtuous containing $3.67 \%$ protein, $5.45 \%$ fat and $22.54 \%$ carbohydrates.

Keywords: traditional food, Kepahiang District, macronutrient 
PENDAHULUAN

Kabupaten Kepahiang merupakan daerah hasil pemekaran dari Kabupaten Rejang Lebong yang berdiri pada 7 Januari 2004 berdasarkan UU No.39 Tahun 2003, dengan motto Kepahiang Kabupaten Alami (Asri Laksana Emas dan Intan). Potensi investasi daerah ini meliputi daerah pariwisata, pertanian, perkebunan dan perik anan (mencakup agribisnis dan agroindustri) hasil kegiatan agraris masyarakat Kepahiang relatif mudah dipasarkan. Ini terkait dengan lokasi kabupaten yang strategis. Letaknya yang berada di daerah perlintasan, ditunjang dengan sarana jalan yang terbilang mulus, dan kemudahan transportasi di dalamnya (Anonim, 2010).

Pangan lokal adalah pangan tradisional yang dihasilkan dari suatu daerah di Indonesia yang terdiri dari berbagai macam makanan olahan makanan pokok, maupun makanan tambahan. Pangan lokal dapat dijadikan sebagai suatu ciri khas di suatu daerah. Kabupaten kepahiang terdapat banyak berbagai jenis makanan olahan yang dibuat dari bahan umbi-umbian, sayursayuran maupun dari buah-buahan yang diolah menjadi berbagai jenis makanan ringan.

Berbagai sumber pangan lokal Di Kabupaten Kepahiang, baik yang telah dibudidayakan maupun yang tumbuh liar, telah dimanfaatkan oleh masyarakat sebagai bahan pangan maupun pelengkap upacara adat. Tanaman pangan lokal yang dimaksud dalam tulisan ini adalah tanaman yang dapat menjadi sumber pangan alternatif yang dapat dijadikan makanan cemilan dan memjadi makanan khas Kabupaten Kepahiang juga menjadi ciri khas pada daerah dan menjdi suatu olahan makanan yang dijadikan makanan oleh-oleh Khas Kabupaten Kepahiang. Tanaman pangan lokal yang telah dimanfaatkan masyarakat sebagai sumber pangan secara turun-temurun adalah umbi-umbian dan kacang- kacangan (Widowati 2001). Sehingga perlunya mengkarakterisasi pangan tradisional di Kabupaten Kepahiang, Provinsi Bengkulu.

\section{METODE PENELITIAN}

\section{Bahan}

Bahan penelitian adalah bahan untuk survei dan produk pangan lokal hasil survei.
Alat
Alat yang digunakan dalam penelitian ini adalah:
1. Alat survei adalah alat tulis, kamera dan kuisioner
2. Alat analisis kimia adalah timbangan, oven, desikator, oven blower, soxhlet, tabung reaksi, labu, erlenmeyer. 


\section{Cara Penelitian}

Penelitian ini dilaksanakan melalui tiga tahapan yaitu sebagai berikut :

Tahap I :Inventarisasi produk pangan lokal di Kabupaten Kepahiang

A. Penentuan lokasi survei

Di Kabupaten Kepahiang terdiri dari delapan kecamatan, untuk mendapatkan data jenis pangan lokal di Kabupaten Kepahiang, peneliti melakukan survei di Kecamatan Kepahiang dan Kecamatan Kabawetan pemilihan lokasi survei dilakukan dengan cara sengaja dengan pertimbangan karena Kecamatan Kabawetan salah satu sentral produsen jenis makanan olahan dan di Kecamatan Kepahiang telah menjadi sentral pusat oleh-oleh di Kabupaten Kepahiang.

B. Penentuan responden

Responden dalam penelitian ini terdiri dari tiga golongan yaitru:

1. Responden penjual yaitu dimana peneliti melakukan penelitian melalui responden penjual dengan cara mendatangi penjual dan memberikan kuisioner dan mengetahui makanan yang khas apa saja yang dijual di Kabupaten Kepahiang peneliti melakukan penelitian yang berlokasikan Di Kecamatan Kepahiang karena Di Kecamatan Kepahiang merupakan sentral penjual makanan oleh - oleh tepatnya di Desa Tebat Monok .
2. Responden produsen yaitu dimana peneliti mengetahui proses pengolahan dari berbagai jenis makanan yang khas Di Kabupaten Kepahiang Provinsi Bengkulu.

3. Responden tokoh adat dimana peneliti mengetahui berbagai jenis makanan yang khas di Kabupaten Kepahiang Provinsi Bengkulu.

C. Pelaksanaan survei

Pelaksanaan survei dilakukan dengan cara mendatangi dan memberikan kuisioner ke penjual, tokoh adat dan produsen yang ada di lokasi yang sudah ditentukan.

\section{Tahap II : Analisis makronutrien produk pangan lokal terdiri dari:}
A. Analisis kadar lemak
(Lehninger (1982)
B . Analisis kadar protein (Sudarmaji dkk, 1996)
C. Analisis kadar karbohidrat (Winarno,.1997)

\section{Sumber Data.}

Sumber data penelitian ini terdiri dari 2 yaitu data primer dan data sekunder. Data primer dilakukan dengan metode observasi dan wawancara kemudian data sekunder dilakukan dengan metode studi pustaka. Observasi yaitu merupakan pengumpulan data dengan cara pengamatan langsung ke objek penelitian, 
wawancara yaitu metode pengumpulan data dengan cara mengadakan tanya jawab atau wawancara langsung kepada responden untuk mendapatkan data yang dibutuhkan dengan alat bantu kuisioner, yang akan dilakukan pada minggu pertama dan ketiga dalam waktu satu bulan. Sedangkan studi pustaka yaitu metode pengumpulan data yang bersumber dari buku-buku atau hasil penelitian terdahulu yang berhubungan dengan masalah penelitian. Kemudian sampel sampel makanan diteliti di laboraturium pertanian atau di laboraturium teknologi industri pertanian.

\section{Analisis Penelitian}

Analisis penelitian ini menggunakan analisis deskriptik yaitu suatu bentuk penelitian yang ditujukan untuk mendeskripsikan fenomenafenomena yang ada, baik fenomena alamiah maupun fenomena buatan manusia. Fenomena itu bisa berupa bentuk, aktivitas, karakteristik, perubahan, hubungan, kesamaan, dan perbedaan antara fenomena yang satu dengan fenomena lainnya (Sukmadinata, 2006)

\section{HASIL DAN PEMBAHASAN}

\section{Produk Pangan Lokal di Kabupaten}

\section{Kepahiang}

$$
\text { Pangan lokal adalah suatu }
$$
makanan yang ada pada di setiap daerah secara spesifik Kabupaten Kepahiang memiliki makanan khas yang sering digunakan saat acara adat, pernikahan, hari menanam padi dan panen hasil kebun. Produk pangan lokal yang ada di Kabupaten Kepahiang dari hasil yang diamati dalam penelitian ini terdapat 18 jenis makanan yang terdiri dari, 8 jenis jajanan 4 jenis lauk pauk dan 6 jenis minuman.

\section{Minuman}

1.Bioa kawo

Bioa kawo adalah sebutan air kopi dari masyarat Desa Kepahiang dari Suku Hejang/Rejang, bioa kawo sebagai minuman khas Rejang dan itu juga dikarenakan Desa Kepahiang.Kabupaten Kepahiang mayoritas petani kopi dan proses pembuatan bioa kawo juga sagat mudah yaitu dengan cara pencampuran gula, kopi dan air dengan takaran sesuai selera.

\section{Cinul}

Cinul adalah sebutan cendol dari masyarakat Desa Kepahiang dari suku hejang/rejang, yang sering dibuat saat hari panen, pesta.cinul ini sama dengan cendol pada umumunya yang membedakan dari proses pengolahannya saja. 
Tabel 1. Karakterisasi Pangan Lokal

\begin{tabular}{|l|l|l|}
\hline \multicolumn{3}{|c|}{ Jenis - Jenis Makanan } \\
\hline \multicolumn{1}{|c|}{ Minuman } & \multicolumn{1}{|c|}{ Lauk Pauk } & \multicolumn{1}{c|}{ Jajanan } \\
\hline Bioh kawo & Gulai lemeah & Serawo \\
\hline Cinul & Gulai buah kepayang & Benik/ lemang \\
\hline Bubur rayak & Nasi berkat & Cucur pandan \\
\hline Senaweh & Punjung & Kue tat \\
\hline Serawo lepang & & Juada tlo \\
\hline Serawo nioa & & Bajik \\
\hline & & Lepek \\
\hline & & Bolu koja \\
\hline
\end{tabular}

Sumber: data primer

\section{Serawo Lepang}

Serawo lepang adalah minuman yang dibuat dari buah lepang atau sebutan lain dari buah timun yang diserut menggunakan sendok dan diberi gula dengan sesui selera.

\section{Serawo nioa}

Serawo nioa adalah minuman yang dibuat dari buah kelapa yang diserut dan dicampur gula, serawo nioa ini sering dibuat oleh masyarakat Suku Rejang pada saat acara penurunan bayi, ruahan.

\section{Bioa Senaweh}

Bioa senaweh adalah rebusan batang senaweh yang diminum airnya sebagai minuman penambah energi ,cara membuat bioa senaweh juga cukup mudah dengan merebus batang senaweh ketika air. Sudah menjadi $1 / 2$ dari air awal dan air berubah warna merah itu sudah cukup,dan bioa senaweh siap diminum

6. Bubur rayak

Bubur rayak adalah salah satu makanan khas Kabupaten Kepahiang yang terbuat dari tepung beras dan proses pengolahan yang langsung diatas wajan ambil sesendok adonan bubur mentah, masukkan ke cetakan cendol. Tekan atau digosok-gosokkan menggunakan punggung sendok tepat diatas kuah bubur yang sedang direbus tadi sehingga adonan berjatuhan kedalam kuah. Kerjakan terus sampai adonan bubur habis. Tambahkan gula pasir dan garam secukupnya.

\section{Lauk Pauk}

1. Gulai Lemeah

Gulai lemeah adalah sebuah nama makanan khas Rejang. Komposisinya 
terdiri dari rebung yang dicincang-cincang dan dicampur ikan air tawar seperti ikan mujair, sepat, maupun ikan-ikan kecil yang hidup di air tawar. Setelah cincangan rebung yang dicampur dengan ikan tersebut diaduk-aduk, maka adonan tersebut disimpan ke dalam wadah yang dilapisi dengan daun pisang dan ditutup rapat-rapat proses fermentasi ini membutuhkan waktu minimal selama tiga hari

\section{Gulai Buah Kepayang}

Gulai buah kepayang adalah suatu gulai yang sering dibuat oleh masyarat kepahiang,karena buah kepayang juga sebagai sejarah tercipta nama Desa Kepahiang Kecamatan Kepahiang karena pada jaman dahulu didaerah itu banyak nya tumbuh batang kepayang, gulai buah kepayang itu dibuat setelah proses perendaman buah kepayang selama 3-5 di air lewat.

\section{Punjung}

Punjung adalah cara penyajian nasi beserta lauk-pauknya dalam bentuk kerucut; karena itu disebut pula 'nasi tumpeng'. Olahan nasi yang dipakai umumnya berupa nasi kuning.

\section{Nasi berkat}

Nasi berkat yaitu makanan yang dibuat dari beras ketan putih yang dimasak dan disajikan dengan gulah merah dan kelapa, proses pengolahan nasi berkat sama dengan proses pengolahan serawo, hal ini hanya membedakan artinya saja, jika serawo kue ketan yang di beri bunga diatasnya ( kelapa dan gula merah) sebagai lambang kecerian adat( pernikahan, penurunan bayi, upacara adat) sedangkan nasih berkat yang cara pernyajian yang berbeda dengan serawo kalau nasi berkat bunganya dibawah dan dibungkusi dengan daun pisang melambangkan kesedihan (musibah kematian.)

\section{Jajanan}

\section{Serawo}

Serawo salah satu makanan khas Kabupaten Kepahiang itu dikarenakan serawo makanan yang wajib ada pada saat acara besar seperti upacara adat, pernikahan, nurun bayi, dan hari panen pada masyarakat Kabupaten Kepahiang terkhusus Suku Rejang, serawo makanan yang terbuat dari beras ketan yang dimasak dan di beri gula merah dan kelapa.

\section{Benik/Lemang}

Lemang merupakan makanan dari beras ketan yang dimasak dalam seruas bambu, setelah sebelumnya digulung dengan selembar daun pisang. Gulungan daun bambu berisi beras ketan dicampur santan kelapa ini kemudian dimasukkan ke dalam seruas bambu lalu dibakar sampai matang. Lemang lebih nikmat 
disantap hangat-hangat. Cara mengkonsumsi lemang berbeda-beda dari daerah ke daerah. Lemang dijadikan makanan perayaan oleh suku Rejang yang disajikan pada pesta-pesta adat mereka. Bagi Suku Rejang. lemang biasa disantap saat hari raya Idul Fitri atau Idul Adha.

\section{Kue cucur}

Kue cucur adalah yang berbentuk bulat dan sering dibuat variasi bulatan bulatan di tengah yang berwarna seperti gorong dan berasa manis dan gemuk rasanya ini sering digunakan pada suku Rejang makanan pendambing acar zikir atau tholibun

4. Juada Tlo

Juada tlo adalah kue yang dibuat menggunakan bahan kelapa gula halus dan sagu ini juga termasuk dari makan khas kabupaten kepahiang

5. Lepek Ubi Kayu

Lepek ubi kayu / singkong merupakan jenis kue atau makanan yang memiliki bahan dasr ubi kayu yang diparut dan d beri garam dan gula kemudian melalui proses pemasakan dengan cara dikukus.

6. Bajik

Bajik adalah kue basah yang dibuat dari ketan kukus dicampur dengan santan dan gula jawa atau gula pasir, namun jika menggunakan gula pasir, harus menambahkan zat pewarna makanan. Setelah kering, adonan dicetak dalam baki atau tampah, baru setelah dingin adonan dapat dipotong potong, karena apabila dalam keadaan panas adonan belum mengeras dan sulit dibentuk (Rochani, 2012). Makanan ini banyak diproduksi secara tradisional oleh masyarakat di berbagai daerah. Terkhusus Kabupaten Kepahiang bajik juga menjadi makanan yang paforit dan banyak disukai oleh masyarakat Kabupaten Kepahiang, bajik ini sering sekali ditemuakan pada acara adat, pesta per5nikahan ataupun pada upacara adat.

7. Bolu koja

Bolu koja adalah makanan khas Kabupaten Kepahiang yang memiliki tekstur kenyal dan lembut. kue ini banyak diminati karena rasanya yang enak. Bolu koja merupakan makanan khas dalam golongan kue yang berasal dari daerah Bengkulu terkhusus didaerah Kabupaten Kepahiang bolu koja menjadi makan paforit dan Khs bagi msyarakat Kabupaten Kepahiang.

8. Kue Tat .

Kue tat adalah kue berbentuk segi empat seperti tart namun dengan tampilan seperti pie, bias anya bertopping nenas. Konon kue ini dulu merupakan makanan khas para raja Bengkulu. Setiap daerah tentunya memiliki makanan unik dan khas tersendiri, termasuk Kabupaten Kepahiang tentunya. Salah satu yang khas di Kabupaten Kepahiang ini adalah kue 
yang bernama Juada Bay Tat. kue berbentuk segi empat ini terbuat dari tepung gandum, gula pasir, telur ayam dan mentega. Setelah kue jadi kemudian barulah dioleskan diatasnya. Rasanya lembut dan sedikit renyah dengan manis selai nenas yang manis mengigit membuat kue ini banyak disukai

\section{Analisis Makronutrien Produk Pangan}

\section{Lokal di Kabupaten Kepahiang}

Makronutrien adalah zat gizi (nutrien) yang memberikan energi bagi tubuh yang diperlukan tubuh dalam jumlah besar untuk bertahan hidup. Terdapat tiga jenis makronutrien yaitu karbohidrat, protein dan lemak, Karbohidrat, protein dan lemak m asingmasing memberikan energi dalam jumlah yang berbeda. Telah diketahui berbagai jenis makanan dan pangan lokal yang khas di Kabupaten Kepahiang, dari berbagai jenis makanan peneliti memilih tiga macam jenis makanan dari keseluruhan makanan yang ada, untuk dilakukan analisa makronutrien, peneliti membuat batasan untuk analisis hanya untuk makanan jajanan saja, dengan menganalisis 3 (tiga) sampel makanan yaitu lemang, serawo dan bajik. Hal ini ditentukan dengan pertimbangan bahan sampel makanan tersebut terbuat dari bahan baku yang sejenis yaitu beras ketan sehingga dimungkinkan memiliki karakterisasi yang hampir serupa. Adapun jenis makanan yang diuji lemang, serawo dan bajik dengan parameter yang diuji kadar lemak, kadar protein dan kadar karbohidrat.

\section{Wajik/Bajik}

Wajik adalah panganan semi basah hasil pengolahan beras ketan, gula dan santan kelapa, dengan atau tanpa penambahan bahan tambahan makanan lainnya (SNI 01-4272-1996). Wajik merupakan makanan tradisional yang telah dikenal masyarakat melayu seperti Indonesia, Malaysia dan Singapura. Wajik biasa disajikan untuk camilan disaat santai. Berbeda dengan hasil olahan beras ketan yang lain seperti jenang, wingko babat maupun krasikan, pada wajik beras ketan tidak ditepungkan terlebih dahulu, sehingga tekstur dari wajik berbeda dari jenang dodol, krasikan maupun wingko babat. Kelebihan dari wajik adalah memiliki rasa yang khas yaitu manis dan legit sehingga cocok sebagai makanan camilan. Secara umum wajik memiliki bentuk persegi empat atau jajar genjang, memiliki tekstur semibasah dan agak lengket karena berasal dari beras ketan yang memiliki kadar amilopektin yang tinggi (Darmadjati, 1980). Oleh karena itu bahan baku beras ketan tidak dapat diganti dengan beras biasa. 
Tabel 2. Analisis Makronutrien Produk Pangan Lokal di Kabupaten Kepahiang

\begin{tabular}{|c|c|c|c|c|}
\hline \multirow{2}{*}{ No } & Sampel & \multicolumn{3}{|c|}{ Parameter } \\
\cline { 3 - 5 } & & $\begin{array}{c}\text { Kadar Protein } \\
(\boldsymbol{\%})\end{array}$ & $\begin{array}{c}\text { Kadar Lemak } \\
(\boldsymbol{\%})\end{array}$ & $\begin{array}{c}\text { Kadar Karbohidrat } \\
(\boldsymbol{\%})\end{array}$ \\
\hline 1 & Lemang & 3,98 & 4,93 & 23,45 \\
\hline 2 & Serawo & 3,87 & 5,12, & 22,89 \\
\hline 3 & Bajik & 3,67 & 5,45 & 22,54 \\
\hline
\end{tabular}

\section{Sumber: data primer}

Rasa dari wajik juga khas, karena menggunakan gula jawa dan santan maka camilan ini berasa legit dan gurih. Secara umum wajik berwarna kecoklatan yang berasal dari gula merah atau gula jawa, namun ada pula wajik yang diinovasi menjadi berwana-warni dengan penambahan pewarna makanan.

Makanan ini banyak diproduksi secara tradisional oleh masyarakat di berbagai daerah. Terkhusus Kabupaten Kepahiang wajik juga menjadi makanan yang favorit dan banyak disukai oleh masyarakat Kabupaten Kepahiang. Berdasarkan SNI 2986:2013 kandungan protein wajik $4,11 \%$ dengan batas minimal 3,0 dan kandungan lemak wajik sebesar $8,78 \%$ dengan batas minimal lemak 5,0\%. Dari hasil analisi telah diketahui kandungan gizi pada wajik yaitu kadar lemak 5,45 \%, kadar protein 3, 67\% dan kadar karbohidrat 22, $54 \%$, sehingga hasil analisi kadar lemak, kadar protein dan kadar karbohidrat sudah memenuhi standar SNI 2986:2013.

\section{Serawo}

Serawo penganan semibasah (Intermediet moisture food) hasil pengolahan beras ketan, gula dan santan kelapa, dengan atau tanpa penambahan bahan tambahan makanan lainnya. Serawo makanan yang terbuat dari beras ketan yang dimasak dan di beri gula merah dan kelapa. Serawo juga tergolong makanan semi basah sama hal nya dengan kue lupis, proses pengolahan kue serawo dan lupis juga sama yang membedakan jenis kue ini terdapat pada cara penyajiannya sehingga peneliti mengambil perbandingan serawo dengan kue lupis. Kue Lupis Ketan adalah makanan cemilan yang biasa dikonsumsi oleh masyarakat Indonesia. Kue Lupis Ketan mengandung energi sebesar 164 kilokalori, protein 1,8\%, karbohidrat 34,5 $\%$, lemak 2,1 \% (Anonim, 2016), dari 
hasil analisis serawo kandungan protein sebesar $3.87 \%$, kandungan lemak 5,12\% dan kandungan karbaohidrat 28,89\%. Karna standar mutu serawo belum ada sehingga penulis membandingkan hasil analisa kandungan protein, lemak dan karbohidrat dari kue lupis. Sehingga dari hasil analisis kandungan protein, lemak dan karbohidrat serawo sudah memenuhi standar mutu,

\section{Lemang/Benik}

Lemang merupakan makanan dari beras ketan yang dimasak dalam seruas bambu, setelah sebelumnya digulung dengan selembar daun pisang. Gulungan daun bambu berisi tepung beras dicampur santan kelapa ini kemudian dimasukkan ke dalam seruas bambu lalu dibakar sampai matang. Lemang lebih nikmat disantap hangathangat. Cara mengonsumsi lemang berbeda-beda dari daerah ke daerah. Ada yang senang menikmatinya dengan cara manis (ditambah selai, kinca, serikaya) atau dengan cara asin (rendang, telur, dan lauk-pauk lainnya), atau ada juga yang memakannya dengan buah-buahan seperti durian. Mengikuti kebanyakan resep, 500 gram tepung pulut dan $750 \mathrm{ml}$ santan kelapa pekat diperlukan bagi menghasilkan sebatang lemang yang baik. Berdasarkan analisis nutrisi menggunakan software nutritionst, anggaran jumlah tenaga didalam sebatang lemang ialah 3,778 kalori yang mana $52 \%$ disumbangkan oleh santan kelapa. Lemper adalah makanan cemilan ringan yang biasa dikonsumsi oleh masyarakat Indonesia. Lemper mengandung energi sebesar 177 kilokalori, protein $3 \%$, karbohidrat 34,7 \%, lemak 2,9 \% Hasil tersebut didapat dari melakukan penelitian terhadap 80 gram lemper, dengan jumlah yang dapat dimakan sebanyak $100 \%$ (Anonim, 2016). Karna tidak ditemukan sumber kandungan protein, lemak dan karbohidrat lemang maka penulis membandingkan dengan kandungan protein, lemak dan karbohidrat lemper. Dari hasil analisis terhadap lemang yang diperoleh dari Kabupaten Kepahiang mengandung karbohidrat 23,45\% kandungan protein 3,98 \% dan kandungan lemak $4,93 \%$ sehingga jika dibandingkan dengan kandungan lemper hasil analisis lemang sudah memenuhi standar.

\section{KESIMPULAN}

Pangan tradisional yang khas di Kabupaten Kepahiang dari hasil yang diamati dalam penelitian ini terdapat 18 jenis makanan yang terdiri dari, 8 jenis jajanan 4 jenis lauk pauk dan 6 jenis minuman. Telah disimpulkan tiga jenis makan itu telah melalui analisis makronutrien dengan parameter yang telah diuji yaitu lemang mengandung 
3,98\% kadar protein 4, 93 kadar lemak dan 23, $45 \%$ kadar karbohidrat. Serawo mengandung 3, $87 \%$ kadar protein 5, 12 kadar lemak dan 22, 89 kadar karbohidrat.dan bajik 3, $67 \%$ kadar protein 5,45 kadar lemak dan 22, 54 kadar karbohidrat.

\section{DAFTAR PUSTAK A}

Arikunto, Suharsimi. 1998. Prosedur Penelitian : Suatu Pendekatan Praktek. : Rineka Cipta. Jakarta Darmasih. 1997 Lokakarya Fungsional Peneliti.Penetapan Kadar Lemak

Lehninger AL. 1982. Dasar Dasar Biokimia Jilid I.Jakarta :Maggy Thenawijaya, Penerjemah Erlangga.Terjemahan dari Principels Of Biochemistry,Jakarta Louhenapessy, J.E. . 2010. Sagu: Harapan Dan Tantangan. Jakarta: Bumi
Aksara. Food Review Referensi Industri \& Teknologi Pangan Indonesia Volume VI No. 10 Oktober 2011.

Mill, geoffrey E, 2000 Tindakan Penelitian, Sebuah Guru Untuk Peneliti.Jesrey:Prentice.Malang

Soekartawi. 1995. Analisis Usahatani. Jakarta: Penebar Swadaya.

Sudarmaji, S, . 1996. Analisa Bahan Makanan dan Pertanian. Penerbit Liberty: Yogyakarta

Sugiyono, 1997, Statistika untuk Penelitian,: Alfabeta Bandung

Sukmadinata. , 2006. Metode Penelitian Pendidikan, Remaja Rosdakarya, Bandung

Widowati, S. dan D.S. Damardjati. 2001. Menggali sumber pangan lokal. Majalah Pangan. Badan Urusan Logistik, Jakarta.

Winarno ,FG.1997.Kimia Pangan dan Gizi : Gramedia Jakarta 